\title{
石灰石による石炭ガス化ガスの高温脱硫方法の検討 ${ }^{\dagger}$
}

\author{
藤岡祐一・土山佳彦・徳田君代 \\ 三菱重工業 (株) 長崎研究研 ${ }^{\dagger \dagger}$ \\ 中島文也・内田 聡 \\ 三菱重工業(株) 原動機事業本部 ${ }^{\dagger \dagger}$
}

\begin{abstract}
石灰石と硫化水素の反応を加圧，高温の固定層および流動層を用いて実験を行った，従 来の流動層石炭ガス化炉へ石灰石を供給する脱硫方法では脱硫率を高くできない理由を明 らかにした．第一の理由はガス化炉における石灰石の反応時間の不足である．第二の理由 は $\mathrm{CaS}$ の酸化反応速度が $\mathrm{CaS}$ の生成速度よりも速いことである. CaSの生成速度とカルシ ネーション速度がほぼ等しいと, 石灰石の CaSへの反応率は $60 \%$ 以上になった. 高温の石 炭ガス化ガスを石灰石で形成した流動層を通過させる実験では, 脱硫後の $\mathrm{H}_{2} \mathrm{~S}$ 濃度が 140 ppmに低減した.
\end{abstract}

\section{緒 言}

石炭はその埋蔵量と供給の安定性から今後とも発電用 然料としての主流を占めると思われる。顕在化する地球 環境問題に適切に対応していくために, $\mathrm{SO}_{\mathrm{x}}, \mathrm{NO}_{\mathrm{x}}$ の排 出量が少なくかつプラント効率の高い火力発電システム の開発が急務である。スチームタービンサイクル単独で は発電端プラント効率は約 $40 \%$ であり ${ }^{5)}$, 実用上の限界 がみえてきた，効率向上を図るべく，ガスタービンとス チームタービンの複合サイクル発電を利用する石炭ガス 化炉の開発が進められている. 供給石炭の全量を石炭力゙ ス化炉で完全ガス化する石炭ガス化複合発電システムの プラント効率は $1250^{\circ} \mathrm{C}$ 級ガスタービンで約 $41 〜 44 \%$ と試 算 ${ }^{9)}$ されている. 最近, 石炭ガス化炬を分割し, 空気で ガス化する流動層石炭ガス化炉と流動層燃焼ボイラから 構成するトッピングサイクル4)，および第二世代 $\mathrm{PFBC}^{7)}$ と名付けられた石炭ガス化発電システムが提案されてい る. その発電端プラント効率は $1250^{\circ} \mathrm{C}$ 級ガスタービンで 約 $44.5 \sim 46 \%$ と試算 ${ }^{9)}$ されている.

トッピングサイクル，第 2 世代 $\mathrm{PFBC}$ とあ下の三つ の理由から, 石炭ガス化炉に打いて石灰石による石炭力゙ ス化ガスの脱硫を指向している．第一の理由は脱硫反応 装置構成がシンプルで消費エネルギーが非常に小さくな ることである．第二の理由は材料を腐食させる $\mathrm{H}_{2} \mathrm{~S}$ 濃度

† 1994年 6 月 1 日受理

†† $\mathbf{0} 81-03$ 長崎市深堀町 5-717-1

†† テ220 横浜市西区みなとみらい3-3-1
を低下させることにより石炭ガス化ガスの顕熱を高温の 水蒸気として回収でき, スチーム発電サイクルの効率向 上が容易になることである，第三の理由は脱硫反応熱が 発電に利用できることである.

現在採用されている脱硫方法は, 流動層石炭ガス化炉 に石灰石を供給し, 石炭から発生する $\mathrm{H}_{2} \mathrm{~S}$ CaSとして 固定した後, $\mathrm{CaS}$ を含む石灰石を流動層燃焼ボイラへ送 り，流動媒体として使用し $\mathrm{CaS}$ を $\mathrm{CaSO}_{4}$ として系外へ排 出するものである. トータルの脱硫反応は Eq. (1)となり, 発熱である.

$$
\mathrm{CaCO}_{3}+\mathrm{H}_{2} \mathrm{~S}+2 \mathrm{O}_{2}=\mathrm{CaSO}_{4}+\mathrm{H}_{2} \mathrm{O}+\mathrm{CO}_{2}
$$

高温, 加圧での石灰石による $\mathrm{H}_{2} \mathrm{~S}$ の脱硫は Eq. (2)ある いはEq.(3)である ${ }^{3,8)}$.

$$
\begin{aligned}
& \mathrm{CaO}+\mathrm{H}_{2} \mathrm{~S}=\mathrm{CaS}+\mathrm{H}_{2} \mathrm{O} \\
& \mathrm{CaCO}_{2}+\mathrm{H}_{2} \mathrm{~S}=\mathrm{CaS}+\mathrm{CO}_{2}+\mathrm{H}_{2} \mathrm{O}
\end{aligned}
$$

石灰石をガス化炉へ供給した Goyal ${ }^{2)}$ の報告では脱硫 されたガスの $\mathrm{H}_{2} \mathrm{~S}$ 濃度は $1100 \mathrm{ppm}$ である. $\mathrm{H}_{2} \mathrm{~S}$ 濃度を本 邦の環境基準に適合させるには $150 \mathrm{ppm}$ 以下を必要とし, 現状では石灰石を石炭ガス化炉へ供給する脱硫方法は実 用に供せない。

我々はかって通産省のサンシャインプロジェクトで開 発した $40 \mathrm{t} / \mathrm{d}$ 流動層石炭ガス化パイロットプラント ${ }^{6)}$ 発展させた, Fig. 1 亿示す構成を次世代流動層石炭ガス 化炉 (AFCG) と名付けて検討中である。次世代流動層石 炭ガス化炉 (AFCG)に組み込む新しい脱硫方法を検討す るために，石灰石と $\mathrm{H}_{2} \mathrm{~S}$ にる高温，加圧の反灾実験を 行った。 


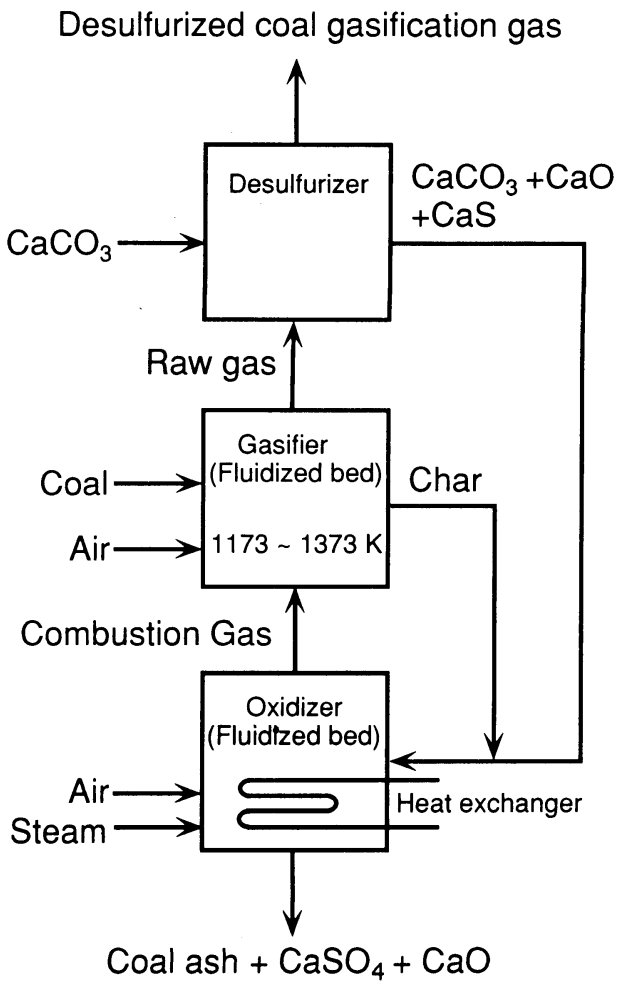

Fig. 1 Advanced fluidized bed coal gasifier

\section{1. 固定層実験}

\section{1 . 1 石灰石試料}

棡山県井倉産の石灰石を粉砕し，ふるい上累積重量50 \%の粒子径が $0.65 \mathrm{~mm}$, トップサイズが $1 \mathrm{~mm}$, アンダー サイズが $0.35 \mathrm{~mm}$ に分級して使用した．石灰石は $94.1 \%$ が $\mathrm{CaCO}_{3}, \mathrm{CaO}$ が $0.7 \%$ である.

\section{$1 \cdot 2$ 固定層実験方法}

実験装置のフローシートと固定層反応器を Fig. 2 亿示 す。電気炬で反応管 (6)を予熱し, 反応管上部より $\mathrm{CO}_{2}$ ガ スを流しながら，反応管下端より石灰石約 $3 \mathrm{~g}$ が入った 試料皿 (5) を反応管へ取り付ける。試料皿の底は白金の網 である， $\mathrm{CO}_{2}$ を流して反応管圧力を上昇させ，反応管温 度を設定温度に安定させる. 以上をセットアップ操作と 呼ぶことにする。

石灰石と $\mathrm{H}_{2} \mathrm{~S}$ の脱硫実験では，七ットアップ操作後に $\mathrm{CO}_{2}$ ガスをTable 1 の (2) に組成を示す $\mathrm{H}_{2} \mathrm{~S}, \mathrm{CO}_{2}, \mathrm{H}_{2}$ お よび $\mathrm{N}_{2}$ を混合した脱硫ガスに切り替え，石灰石と $\mathrm{H}_{2} \mathrm{~S}$ の 反応を開始させる、試料部の反応管の空塔断面積基準で 約 $0.3 \mathrm{~m} / \mathrm{s}$ にガス流速を設定した. 反応管出口の $\mathrm{H}_{2} \mathrm{~S}$ 濃 度が反応管入口の $\mathrm{H}_{2} \mathrm{~S}$ 濃度に復帰したら, 脱硫ガスを $\mathrm{CO}_{2}$ ガスへ切り替えて反応管圧力を减圧し，石灰石を反応管 から取り出す. $\mathrm{CaCO}_{3}$ が $\mathrm{CaS}$ 転化したモル割合を $\mathrm{CaS}$

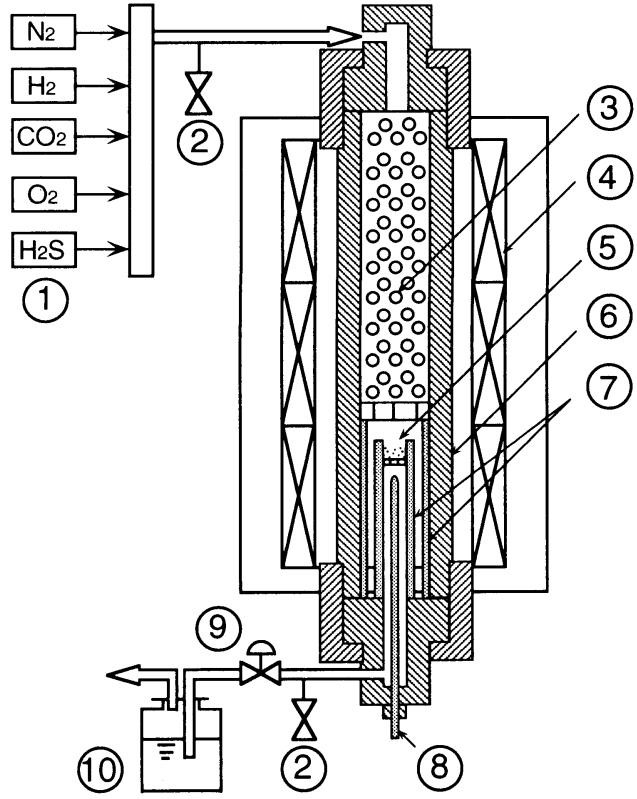
(1) Gas Cylinders
(2) Sampling Port
(3) Alumina Balls
(4) Electric Heater
(5) Limestone

Fig. 2 Pressurized fixed bed experimental apparatus

生成率と定義する。

Eq. (4)のカルシネーション実験では, セットアップ後 $\mathrm{CO}_{2}$ ガスをTable 1 の (3) に示す $\mathrm{CO}_{2}, \mathrm{H}_{2}$ および $\mathrm{N}_{2}$ を混 合したカルシネーションガスへ切り替える. カルシネー

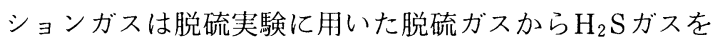
除いた組成である.

$$
\mathrm{CaCO}_{3}=\mathrm{CaO}+\mathrm{CO}_{2}
$$

$\mathrm{CaCO}_{3}$ が $\mathrm{CaO}$ へ転化した割合を $\mathrm{CaO}$ 生成率と呼ぶ。 $\mathrm{CaO}$ 生成率は実験前後の重量変化加算出した.

$\mathrm{H}_{2}, \mathrm{CO}, \mathrm{N}_{2}, \mathrm{CO}_{2}$ の各濃度の測定にはTCD検出器付き のガスクロマトグラフィー(ガスクロ工業 GC-302), $\mathrm{H}_{2} \mathrm{~S}$ はFPD検出器付きのガスクロマトグラフィー（島津 GC$7 \mathrm{~A}$ ), $\mathrm{SO}_{2}$ は非分散型赤外線複光束変位作動法（柳本 $\mathrm{EIR}-\mathrm{S}), \mathrm{O}_{2}$ はジルコニア式(日本ガイシ $\mathrm{SH}-2 \mathrm{D}$ ) を用い た. 粒子中の全 $\mathrm{Ca}$ 濃度はEDTA 滴定法, $\mathrm{CaS}^{2}$ は $\mathrm{S}^{2-}$ とし てメチレンブルー吸光光度法, $\mathrm{CaSO}_{4}$ は $\mathrm{SO}_{4}{ }^{2-}$ として硫 酸バリウム沈殿法, $\mathrm{CaCO}_{3}$ は $\mathrm{CO}_{3}{ }^{2-}$ として水酸化バリウ ム吸収法により分析した。石灰石中の $\mathrm{CaO}$ は全 $\mathrm{Ca}$ 濃度 から $\mathrm{CaS}, \mathrm{CaCO}_{4}, \mathrm{CaCO}_{3}$ を差し引いて計算で求めた。

セットアップ操作の雾囲気ガス セットアップ操作 
Table 1 Experimental condition of pressurized fixed bed

(1) (2) (3) (4)

Reaction gas Setting Desulfuri- Calcination Oxidation up

\begin{tabular}{|c|c|c|c|c|c|}
\hline $\mathrm{H}_{2}$ & $\%$ & 0 & 20 & 20 & 0 \\
\hline $\mathrm{CO}_{2}$ & $\%$ & 100 & 15 & 15 & 15 \\
\hline $\mathrm{H}_{2} \mathrm{~S}$ & ppm & 0 & $640 \sim 1020$ & 0 & 0 \\
\hline $\mathrm{O}_{2}$ & $\%$ & 0 & 0 & 0 & 0 \\
\hline $\begin{array}{ll}\mathrm{N}_{2} \\
-\cdots\end{array}$ & $\%$ & balance & balance & $\begin{array}{l}\text { balance } \\
\text { b............... }\end{array}$ & $\begin{array}{l}\text { balance } \\
\text {.............. }\end{array}$ \\
\hline \multicolumn{6}{|c|}{ Temperature $1106 \sim 1223 \mathrm{~K}$, Pressure $0.22 \sim 1.6 \mathrm{MPa}$} \\
\hline \multicolumn{6}{|c|}{ Gas velocity of fixed bed $0.3 \mathrm{~m} / \mathrm{s}$, Limestone $3 \mathrm{~g}$} \\
\hline
\end{tabular}

に約 $15 \mathrm{~min}$ を要す。セットアップの過程で $100 \%$ 濃度の $\mathrm{N}_{2}$ ガスを流しておくと，実験での $\mathrm{CaS}$ 生成率の再現性が悪 かった．濃度 $100 \%$ 叔 ガスを流しながらいったん温度

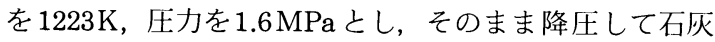
石を取り出してみると, $\mathrm{CaO}$ が50\%以上生成していた。 $100 \%$ の $\mathrm{CO}_{2}$ ガスを流しながら同様の操作をすると，時 間が多少変化しても $\mathrm{CaO}$ の生成率は約 $5 \%$ 以下に抑えら れた。セットアップ操作で温度を安定させる間の $\mathrm{CaO}$ 生 成量が， $\mathrm{CaS}$ 生成率に影響を与えた。 $100 \% の \mathrm{CO}_{2}$ ガスで セットアップ操作を行うことで, $\mathrm{CaS}$ 生成率の実験再現 性がよくなり土 $5 \%$ 程度に収まるようになった。セット アップ操作および反応を終了させ試料取り出す操作の時 には $100 \%$ の $\mathrm{CO}_{2}$ ガスを流すことにした.

\section{反応管内の $\mathrm{H}_{2} \mathrm{~S}$ ガスの吸着 Fig. 3 亿脱硫実験例を} 示す. Fig. 3 の (1) 脱硫の点線は石灰石がない場合の $\mathrm{H}_{2} \mathrm{~S}$ 濃度の経時変化を示す. ガスの予熱用として反応管内に 充填したアルミナボール (3), 反応管内面の金属, および 白金網等により $\mathrm{H}_{2} \mathrm{~S}$ の吸着と分解が生起すると考えられ た. 試料皿に石灰石を充填せず脱硫ガスを流し，Fig. 3 の (1) 脱硫の点線で示すような $\mathrm{H}_{2} \mathrm{~S}$ の濃度の経時変化が 起きた後, 引き続いてカルシネーションガスへ切り替える と反応管内に吸着された $\mathrm{H}_{2} \mathrm{~S}$ が約10～15分で脱着された． 再度脱硫ガスを流しても，ほぼ同様のFig. 3の(1) 脱硫 の点線の濃度変化が生じたので, 脱硫ガスの $\mathrm{H}_{2} \mathrm{~S}$ 濃度の 初期減少は吸着が主体と考えた。同様の操作を各温度で 行い, 石灰石を充填しない場合の $\mathrm{H}_{2} \mathrm{~S}$ 濃度変化を取得し た.Fig.3の (1) 脱硫の実線は石灰石セットした場合を示 す. 実線と点線の間の斜線の区間を $\mathrm{H}_{2} \mathrm{~S}$ と石灰石の反応 による $\mathrm{CaS}$ 生成量とした。

CaS生成率の算出方法 固定層出口のガスの硫黄化 合物として $\mathrm{H}_{2} \mathrm{~S}$ みを計測し， COSを計測していない。 後述の流動層実験では $\mathrm{H}_{2} \mathrm{~S}$ の一部が $\mathrm{COS}$ 一転換し, COS 濃度は $\mathrm{H}_{2} \mathrm{~S}$ 濃度の10分の 1 程度になった。

上述のように本実験の誤差の要因として反応開始時の

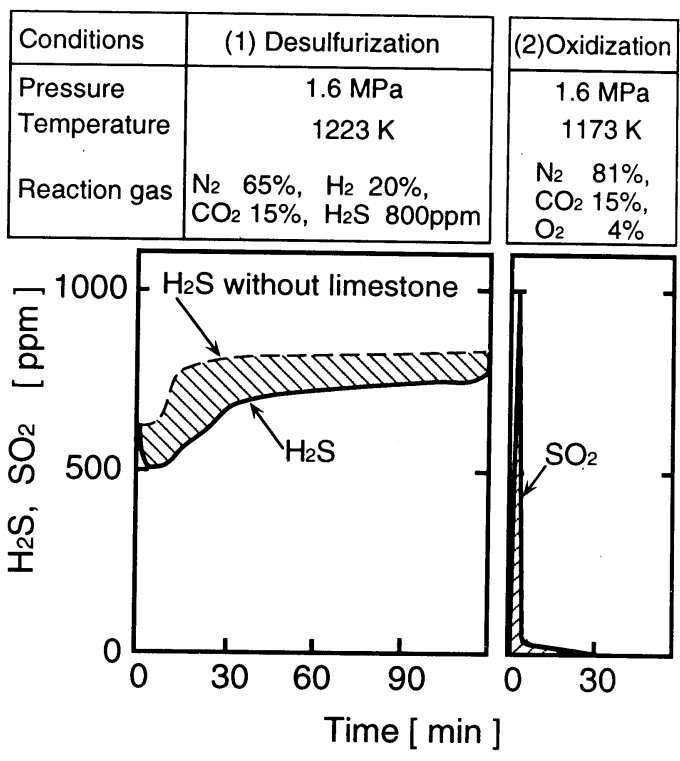

Fig. 3 Product gas profiles at both CaS formation and $\mathrm{CaS}$ oxidation reaction

石灰石内の $\mathrm{CaO}$ 生成率, 反応管内の $\mathrm{H}_{2} \mathrm{~S}$ の吸着, 分解, およびCOSの発生がある。しかし，実験値の再現性は士 $5 \%$ あり, $\mathrm{H}_{2} \mathrm{~S}$ から算出した $\mathrm{CaS}$ 生成率で脱硫反応の定 性的な検討は可能であると考えている.

\section{$1 \cdot 3$ 固定層実験結果}

脱硫およびカルシネーション実験 温度が約1100〜 $1250 \mathrm{~K}$, 反応器圧力が約 $0.22 \sim 1.6 \mathrm{MPa}$ の範囲で実験を 行った. Fig. 4 亿压力約 $0.25 \mathrm{MPa}$ で温度を变化させた場 合のカルシネーション反応による $\mathrm{CaO}$ 生成率と脱硫反応 による $\mathrm{CaS}$ 生成率の経時変化を示す。温度が $1106 \mathrm{~K}$ と $1155 \mathrm{~K}$ では CaS生成速度はほぼ同じであった。温度を

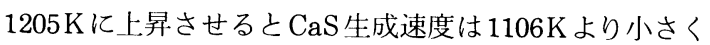
なった。 $1223 \mathrm{~K}$ のルシネーション反応が完了した $30 \mathrm{~min}$ 以降は，同温度での $\mathrm{CaS}$ の生成反応が進まず, $\mathrm{CaS}$ 生成 率は約 $9 \%$ で増加が止まった. Fig. 5 亿压力 $0.8 \mathrm{MPa} の$ 実験結果を示す. $1122 \mathrm{~K}$ ではカルシネーション反応が進 まず， $\mathrm{CaS}$ の生成率の増加は $4 \%$ で止まった。 $1161 \mathrm{~K}$ と $1208 \mathrm{~K}$ ではカルシネーション反応速度は異なるが, $\mathrm{CaS}$ 生成速度はほぼ同じであった．Fig. 6 亿1.6 MPa の実験 結果を示す. $1118 \mathrm{~K}$ ではカルシネーション反応が進まず, $\mathrm{CaS}$ の生成率の増加は $0.6 \%$ で止まった。温度が上昇し力 ルシネーション反応が速くなると CaS 生成率の増加速度 が大きくなった. 固定層出口のガスはほぼ $\mathrm{CO}_{2}+\mathrm{H}_{2}=\mathrm{CO}$ $+\mathrm{H}_{2} \mathrm{O}$ の反応の平衡值にシフトしていた.

Fig. 4, 5, 6 から $\mathrm{CaS}$ 生成率の 0 〜 20\%の区間の傾きを 初期脱硫反応速度 $r\left[\mathrm{~min}^{-1}\right]$ (毎分当たり石灰石単位モル 当たり反応する $\mathrm{H}_{2} \mathrm{~S} モ ル$ 量）とする. 初期脱硫反応速度 

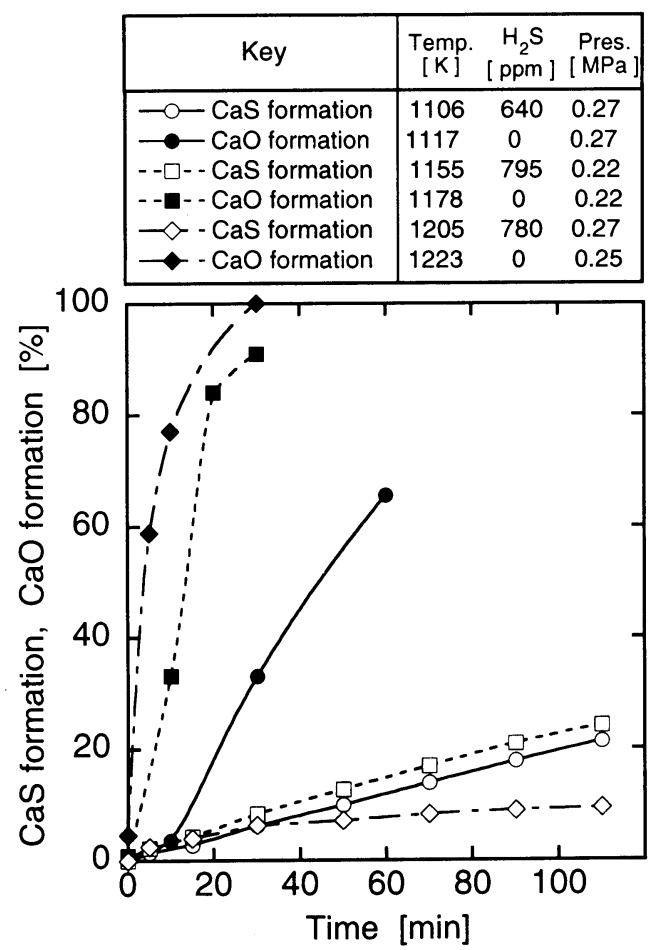

Fig. 4 Reactions between limestone and $\mathrm{H}_{2} \mathrm{~S}$, and calcination at $0.25 \mathrm{MPa}$
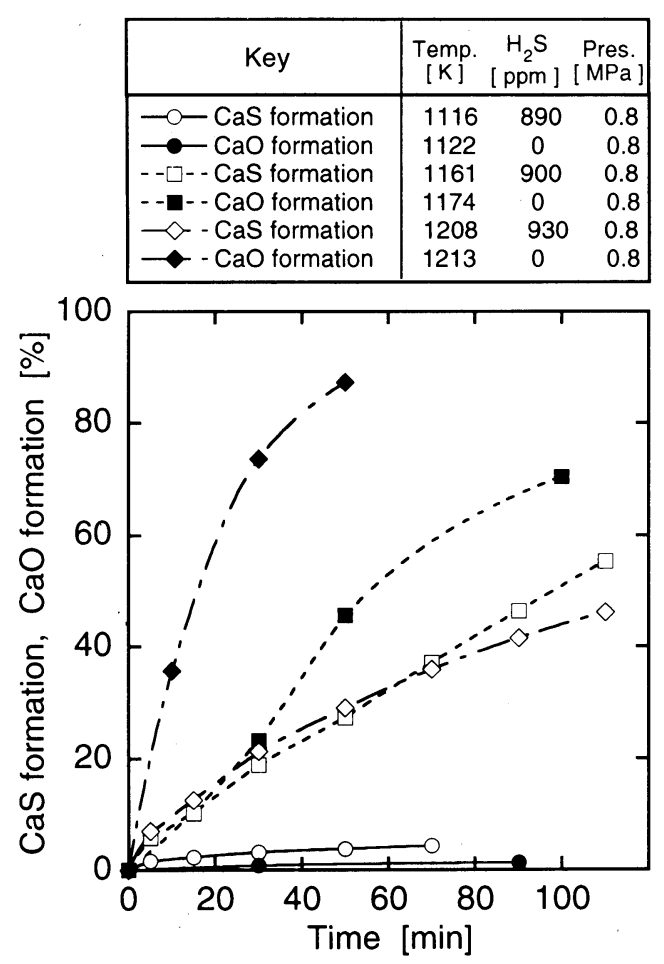

Fig. 5 Reactions between limestone and $\mathrm{H}_{2} \mathrm{~S}$, and calcination at $0.8 \mathrm{MPa}$
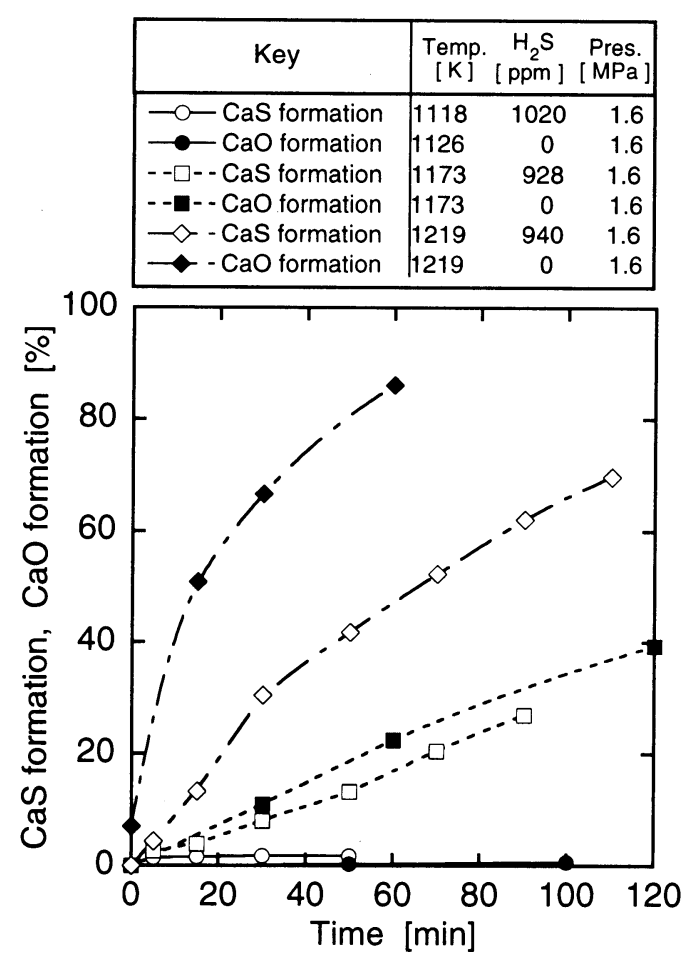

Fig. 6 Reactions between limestone and $\mathrm{H}_{2} \mathrm{~S}$, and calcination at $1.6 \mathrm{MPa}$

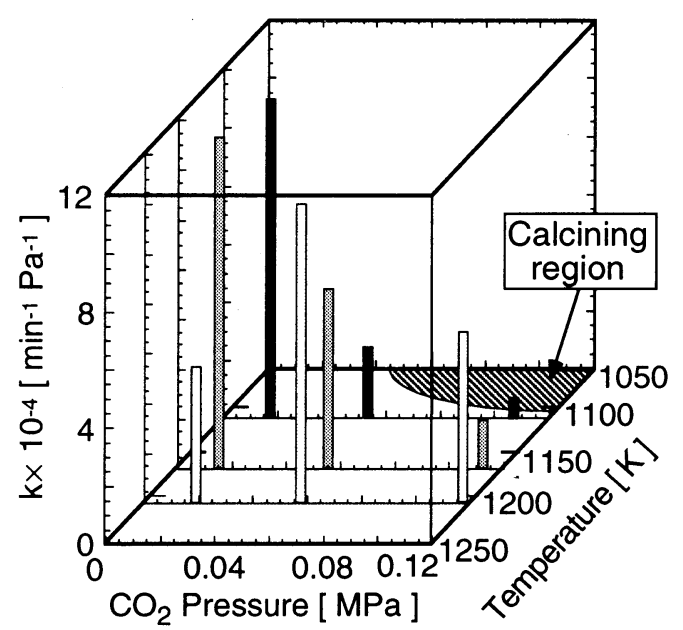

Fig. 7 Effect of temperature and $\mathrm{CO}_{2}$ pressure on reaction constant of desulfurization

$r$ が Eq.(5)のように $\mathrm{H}_{2} \mathrm{~S}$ のガス分圧 $P_{H_{2} S}[\mathrm{~Pa}]$ に比例す ると仮定する.

$$
r=k P_{H_{2} S}
$$

Fig. 7 亿初期反応速度定数 $k$ と温度と $\mathrm{CO}_{2}$ 分圧の関係を 示す. Fig. 7 の温度, $\mathrm{CO}_{2}$ 分圧平面上の斜線領域はカル シネーション反応の化学平衡から計算される $\mathrm{CO}_{2}$ 分圧か 実際のガス中の $\mathrm{CO}_{2}$ 分圧よりも小さい範囲を示す. 
Table 2 Analyses of coal

\begin{tabular}{|c|c|c|}
\hline Coal & $\mathrm{T}$ & $\mathrm{N}$ \\
\hline \multicolumn{3}{|c|}{ Proximate analysis $[\%]$} \\
\hline moisture & 5.4 & 1.4 \\
\hline F.C. & 35.8 & 58.0 \\
\hline V.M. & 43.3 & 25.8 \\
\hline ash & 15.5 & 14.8 \\
\hline $\begin{array}{l}\text { Total-S } \\
\text {............... }\end{array}$ & 0.3 & 0.3 \\
\hline \multicolumn{3}{|c|}{ Ultimate analysis $[\%]$ (moisture free) } \\
\hline $\mathrm{C}$ & 65.7 & 73.7 \\
\hline $\mathrm{H}$ & 5.2 & 4.4 \\
\hline Combustible-S & 0.13 & 0.28 \\
\hline $\mathrm{O}$ & 11.9 & 5.2 \\
\hline $\mathrm{N}$ & 1.0 & 1.4 \\
\hline
\end{tabular}

CaS 酸化実験 石灰石試料と $\mathrm{H}_{2} \mathrm{~S}$ を反応させて CaS を生成させ, 試料を取り出す. 試料の取り出しのために, 反応管の压力を下げる際に $\mathrm{SO}_{2}$ が発生した. 発生した $\mathrm{SO}_{2}$ を正確に定量できないが，モル比で試料の全 Caの $1 \%$ 程 度に相当する量と推定された。 反応管内に吸着した $\mathrm{H}_{2} \mathrm{~S}$ をパージ後, 試料を反応管にセットしTable 1の(4)に示 す $\mathrm{O}_{2}, \mathrm{CO}_{2}, \mathrm{~N}_{2}$ の混合ガスを $\mathrm{CaS}$ の酸化用ガスとして流 すと, Fig. 3 の (2) 酸化に示すように $\mathrm{SO}_{2}$ が発生する.

$\mathrm{CaS}$ 生成反応がほぼ完了するのに $120 \mathrm{~min}$ を要するに対 し, $\mathrm{O}_{2}$ による $\mathrm{CaS}$ 酸化反応は約 $10 \mathrm{~min}$ で完了する. $\mathrm{H}_{2} \mathrm{~S}$ 濃度から $\mathrm{CaS}$ 生成率を計算すると $60.4 \%$ である。酸化後 の試料を取り出し分析すると, $\mathrm{CaCO}_{3}, \mathrm{CaS}, \mathrm{CaO}, \mathrm{CaSO}_{4}$ がモル比でそれぞれ $16.7 \%, 33.1 \%, 45.0 \%, 5.2 \%$ あった. 酸化後の試料中の $\mathrm{CaO}$ は $\mathrm{CaS}$ から $22.1 \%$ 生成すると計算 される $\mathrm{SO}_{2}$ は $22.1 \%$ 発生することになる。しかし, ガス 側の $\mathrm{SO}_{2}$ 濃度からは $\mathrm{SO}_{2}$ 発生量は約 $10 \%$ であり，組成 分析とガス分析の $\mathrm{SO}_{2}$ 発生量が一致しない. $\mathrm{SO}_{2}$ の計測 には計測器の応答遅れがあり, $\mathrm{SO}_{2}$ 濃度が $0 \mathrm{ppm}$ から 1000 ppm のガスに切り替えた場合の 2 分後の計器の指示値は 約 900 ppm であった. Fig. 3 の CaS 酸化実験では切り替 え直後に発生した $\mathrm{SO}_{2}$ 濃度が計測できなかったと推定さ れる。

\section{2. 流動層実験}

\section{$2 \cdot 1$ 石 炭 試 料}

原炭をロールミルで粉砕, 乾燥後, ふるい上累積重量 $50 \%$ の粒子径が $0.8 \mathrm{~mm}$, トップサイズが $2 \mathrm{~mm}$, アンダー サイズが $0.5 \mathrm{~mm}$ に分級した石炭を使用した. Table 2 に 工業分析値と元素分析值を示す.

使用した石灰石は固定層実験と同じもので，石灰石の 状態では常圧, 常温の流動化開始速度は $0.21 \mathrm{~m} / \mathrm{s}$, カル シネーション後の石灰石では $0.17 \mathrm{~m} / \mathrm{s}$ であった。

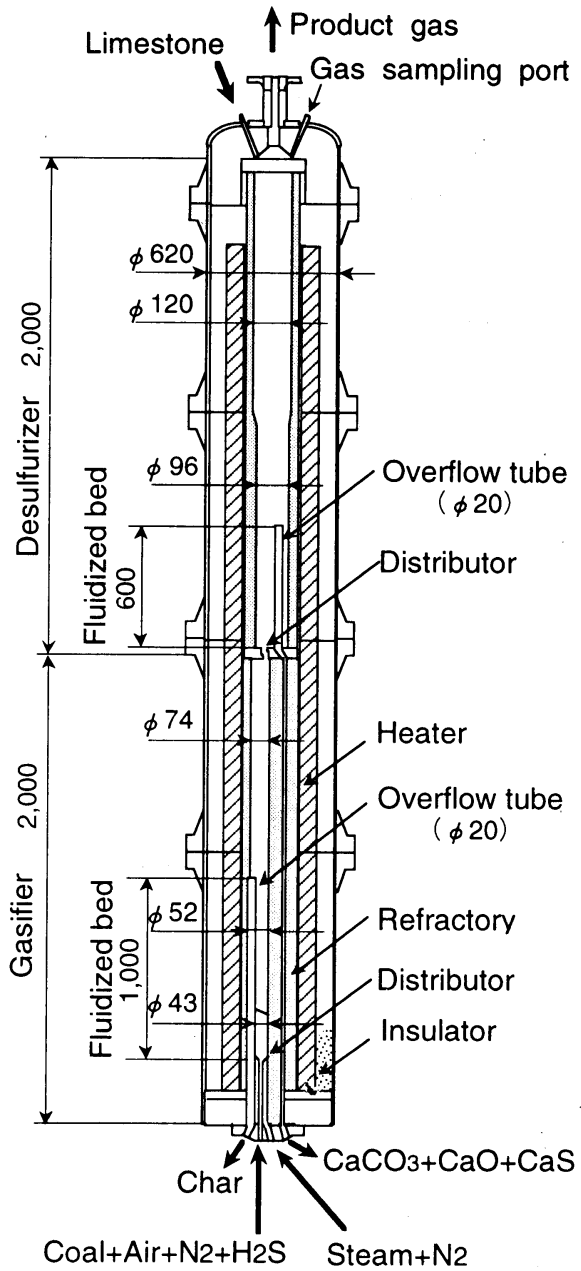

Fig. 8 Pressurized fluidized bed reactor for desulfurization

\section{2 - 2 流動層実験方法}

反応器はFig. 8 に示すように, 下部を石炭で流動層を 形成させるガス化炉とし，上部を石灰石で流動層を形成 させる脱硫炉としている。 ガス化炉底部のガス流速を $1.1 \mathrm{~m} / \mathrm{s}$ 亿設定し, 脱硫炉ガス流速は流動化開始速度の約 2 倍とし， $0.36 〜 0.4 \mathrm{~m} / \mathrm{s}$ に設定した。

石炭を空気で気流搬送してガス化炉の炉底のガス分散 板の中心より供給する. ガス分散板の石炭供給ノズルの 周讲から窒素抢よび水蒸気を供給する。 $\mathrm{H}_{2} \mathrm{~S}$ を供給する 場合は不炭供給用の空気に混入する，ガス化炉を電気炉 で外熱し， $1273 \mathrm{~K}$ 以上で数時間以上予熱した後，石炭と 空気を供給し, 石炭着火後に水蒸気を供給し, 徐々に温 度とガス流速を目標値へ設定して行く.

ガス化炉から発生するガス組成が安定したら，脱硫炉 の上部から石灰石あるいは前回使用した脱硫炉の流動材 
Table 3 Comparison of desulfurization efficiency by feeding portion of limestone into fluidized bed apparatus

\begin{tabular}{|c|c|c|c|c|}
\hline \multicolumn{5}{|l|}{ Desulfurization } \\
\hline Limestone & - & None & Gasifier & Desulfurizer \\
\hline Feed & $\mathrm{kg} \mathrm{h}^{-1}$ & 0 & 0.38 & 0.34 \\
\hline $\mathrm{Ca} / \mathrm{S}$ & - & 0 & 2.1 & 1.92 \\
\hline Temperatüre & $\mathrm{K}$ & 1193 & 1199 & 1217 \\
\hline $\begin{array}{l}\text { Efficiency } \\
\end{array}$ & $\%$ & 15.9 & $\begin{array}{r}29.3 \\
\ldots . . . .\end{array}$ & 77.2 \\
\hline \multicolumn{5}{|l|}{ Gasification } \\
\hline Coal (N) & $\mathrm{kg} \mathrm{h}^{-1}$ & 10.6 & 11.2 & 9.8 \\
\hline Air & $\mathrm{kg} \mathrm{h}^{-1}$ & 22.2 & 22.2 & 19.4 \\
\hline $\mathrm{N}_{2}$ & $\mathrm{kgh}^{-1}$ & 11.5 & 11.1 & 12.0 \\
\hline Feed $\mathrm{H}_{2} \mathrm{~S}$ & $\mathrm{molh}^{-1}$ & 0.94 & 0.85 & 0.94 \\
\hline Steam & $\mathrm{kg} \mathrm{h}^{-1}$ & 1.5 & 1.5 & 1.5 \\
\hline Temperature & $\mathrm{K}$ & 1208 & 1236 & 1209 \\
\hline Pressure & $\begin{array}{l}\mathrm{MPa} \\
\ldots \ldots\end{array}$ & 1.3 & $\begin{array}{c}1.3 \\
\ldots \ldots . .\end{array}$ & 1.3 \\
\hline \multicolumn{5}{|l|}{ Production gas } \\
\hline $\mathrm{H}_{2} \mathrm{~S}$ & ppm & 934 & 773 & 249 \\
\hline $\cos$ & ppin & 76 & 67. & 21 \\
\hline $\mathrm{H}_{2} \mathrm{O}$ & & 13.2 & 14.7 & 13.6 \\
\hline $\mathrm{H}_{2}$ & & 5.0 & 5.0 & 4.4 \\
\hline $\mathrm{CH}_{4}$ & $\%$ & 1.8 & 1.6 & 1.6 \\
\hline $\mathrm{CO}_{2}$ & & 7.9 & 7.8 & 6.85 \\
\hline $\mathrm{CO}$ & & 4.6 & 4.5 & 4.91 \\
\hline
\end{tabular}

を供給して, 脱硫剤の流動層を形成する. その後, 脱硫 炉上部より石灰石をスクリューフィーダを用いて条件に 応じた量供給する。

温度が約 $1100 \mathrm{~K}$ のリーボード上部执よび反応器の後 流の温度が約 $800 \mathrm{~K}$ のイクロン出口よりガスを採取し, $\mathrm{H}_{2} \mathrm{~S}$ とCOSを計測した。 $\mathrm{H}_{2} \mathrm{~S}$ 濃度はサンプリング管の先 端に設㯰したダストフィルターの微粒子捕集量が増大す ると計測 $\mathrm{H}_{2} \mathrm{~S}$ 濃度が低下した。窒素ガスでフィルターを 逆洗すると計測 $\mathrm{H}_{2} \mathrm{~S}$ 濃湾が最初の值に復㷌した。サイク ロン出口ガス採取用のダストフィルターは常温の部分に 設置した。サイクロン出口のガスの計測值は逆洗直後の フリーボード上部のガス計測值とほぼ一致した。サイク ロン出口の計測值を $\mathrm{H}_{2} \mathrm{~S}, \operatorname{COS}$ 濃度として採用した。 ガス化炉のオーバーフロー管高さは $1000 \mathrm{~mm}$ である. 流動層内のチャー重量を排出チャ一重量で除した值を石 炭の流動層滞留時間と考えると, 流動層滞留時間は10 $15 \mathrm{~min}$ である．脱硫炉のオーバーフロー管高さは $600 \mathrm{~mm}$ である. 石灰不の流動層滞留時間は $2 \sim 6 \mathrm{~h}$, 流動層ガス 滞留時間は約 $1.5 \mathrm{~s}$ である.

\section{$2 \cdot 3$ 流動層実験結果}

脱硫万法と脱硫性能 脱硫率と $\mathrm{Ca} / \mathrm{S}$ 比をモル単位 として次のように定義する.

脱硫率 $=100-($ 脱硫ガス中の硫黄量 $) /($ 供給した不炭 中の燃焼性硫黄之添加した $\mathrm{H}_{2} \mathrm{~S}$ の硫黄量の
Table 4 Typical desulfurization results obtained by feeding limestone into desulfurizer in fluidized bed apparatus

\begin{tabular}{|c|c|c|c|c|}
\hline No. & & 1 & 2 & 3 \\
\hline \multicolumn{5}{|l|}{ Desulfurization } \\
\hline $\mathrm{Ca} / \mathrm{S}$ & - & 1.63 & 1.34 & 5.02 \\
\hline Limestone & $\mathrm{kg} \mathrm{h}^{-1}$ & 0.31 & 0.29 & 0.39 \\
\hline Temperature & $\mathrm{K}$ & 1226 & 1220 & 1228 \\
\hline Efficiency & $\%$ & 86.0 & 85.6 & 59.2 \\
\hline \multicolumn{5}{|l|}{ Gasification } \\
\hline Coal & $\mathrm{kg} \mathrm{h}^{-1}$ & $10.9(\mathrm{~T})$ & $8.0(\mathrm{~N})$ & $9.0(\mathrm{~N})$ \\
\hline Air & $\mathrm{kgh}^{-1}$ & 30.5 & 21.4 & 20.6 \\
\hline $\mathrm{N}_{2}$ & $\mathrm{kgh}^{-1}$ & 8.8 & 11.7 & 12.6 \\
\hline Feed $\mathrm{H}_{2} \mathrm{~S}$ & $\mathrm{molh}^{-1}$ & 1.25 & 1.38 & 0 \\
\hline Steam & $\mathrm{kgh}^{-1}$ & 0 & 1.5 & 1.5 \\
\hline Temperature & $\mathrm{K}$ & 1228 & 1287 & 1228 \\
\hline Pressure & $\mathrm{MPa}$ & 1.3 & 1.3 & 1.3 \\
\hline \multicolumn{5}{|l|}{ Production gas } \\
\hline $\mathrm{H}_{2} \mathrm{~S}$ & \multirow{2}{*}{$\mathrm{ppm}$} & 126 & 182 & 178 \\
\hline $\cos$ & & 13 & 17. & 16 \\
\hline $\mathrm{H}_{2} \mathrm{O}$ & & 5.0 & 9.7 & 11.1 \\
\hline $\mathrm{H}_{2}$ & & 10.0 & 5.7 & 4.7 \\
\hline $\mathrm{CH}_{4}$ & $\%$ & 2.0 & 1.3 & 1.4 \\
\hline $\mathrm{CO}_{2}$ & & 4.5 & 9.4 & 11.0 \\
\hline $\mathrm{CO}$ & & 16.7 & 6.5 & 4.6 \\
\hline
\end{tabular}

和) $\times 100$

$\mathrm{Ca} / \mathrm{S}$ 比 $=($ 石灰石中の $\mathrm{Ca}$ 量 $) /($ 石炭中の硫黄と添加 した $\mathrm{H}_{2} \mathrm{~S}$ の硫黄量の和)

石灰石を石炭に添加してガス化する場合と，ガス化し たガスを脱硫炉の石灰石流動層を通過させて脱硫する場 合の脱硫率を比較した，石炭のガス化条件之脱硫実験結 果を Table 3 に示す. 石灰石を添加しない石炭をガス化 してあ脱硫率は16\%になった． Ca/S 比 2 の石灰石を添加 した石炭をガス化すると脱硫率は約 $30 \%$ にった。石灰 石を添加しない石炭をガス化し， $\mathrm{Ca} / \mathrm{S}$ 比 2 の石灰石を脱 硫炉に供給すると脱硫率は77\%に向上した。

脱硫温度別置の石灰石脱硫炉とすると, 脱硫性能 が向上することから，乙の形式の脱硫特性を調べた。 T 炭を使用し， $\mathrm{Ca} / \mathrm{S}$ 比を 2 , ガス化ガス中の水蒸気濃度を 約 $5 \%$ の一定值に保って脱硫炉の温度を变化させた。実 験の代表的な条件と結果を Table 4 の No.1 亿示す. 石炭 ガス化炉へ供給された石炭の燃焼性硫黄と添加 $\mathrm{H}_{2} \mathrm{~S}$ が $100 \%$ ガス化ガスへ移行したとすると $\mathrm{H}_{2} \mathrm{~S}+\mathrm{COS}$ 濃度は 約 950 ppm よなる. Fig. 9 亿示すように脱硫炉の温度の 上昇により脱硫性能が向上し，1203K以上でほぼ一定と なった。 $\mathrm{H}_{2} \mathrm{~S}+\mathrm{COS}$ 濃度は $140 \mathrm{ppm}$ まで低下した。

Squires $^{8)}$ らがまとめた Eq. (2)の反応の平衡定数をEq. (6) に示す. $T$ は温度 $[\mathrm{K}], P_{\mathrm{H}_{2} \mathrm{O}}$ は水蒸気分压である. Eq. (6) から計算される平衡 $\mathrm{H}_{2} \mathrm{~S}$ 濃度をFig. 9 の点線で 


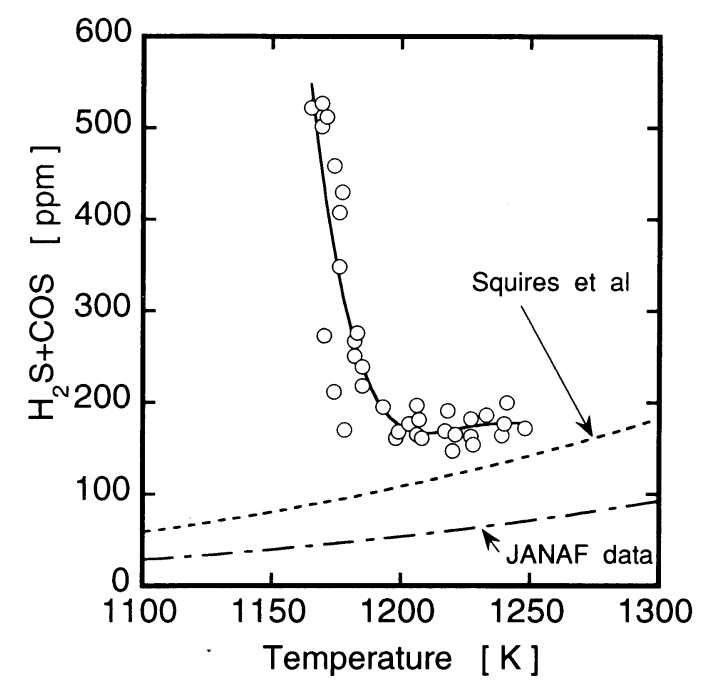

Fig. 9 Effect of temperature on $\mathrm{H}_{2} \mathrm{~S}+\mathrm{COS}$ concentration at desulfurizer outlet

示す. $\mathrm{JANAF}^{11}$ のデータから求めた平衡定数を Eq.(7)に 示す. Eq.(7) から計算される平衡 $\mathrm{H}_{2} \mathrm{~S}$ 濃度を一点鎖線で 示す.

$$
\begin{aligned}
& \log _{10}\left(P_{\mathrm{H}_{2} \mathrm{O}} / P_{\mathrm{H}_{2} \mathrm{~S}}\right)=3519.2 / T-0.268 \\
& \log _{10}\left(P_{\mathrm{H}_{2} \mathrm{O}} / P_{\mathrm{H}_{2} \mathrm{~S}}\right)=3657.1 / T-0.0804
\end{aligned}
$$

$\mathrm{Ca} / \mathrm{S}$ 比の影響 石灰石量の変化とガス化炉へ添加す る $\mathrm{H}_{2} \mathrm{~S}$ 量を変化させて $\mathrm{Ca} / \mathrm{S}$ 比を変化させた。 $\mathrm{N}$ 炭を使 用し, ガス化ガス中の水蒸気濃度を約 $10 \%$, 脱硫炉の温 度は1173〜1228Kであった。実験の代表的な条件と結果 をTable 4 のNo.2, 3 亿示す. Fig.10に示すように, $\mathrm{Ca} / \mathrm{S}$ 比を増大させても, 脱硫炬出口ガスの $\mathrm{H}_{2} \mathrm{~S}+\mathrm{COS}$ 濃度の 減少量は小さかった。

水蒸気分压の影響 $\mathrm{Ca} / \mathrm{S}$ 比を 2 , 温度を $1173 \sim 1223$ $\mathrm{K}$ でのガス化ガス中の水蒸気濃度と脱硫炉出口 $\mathrm{H}_{2} \mathrm{~S}+$ COS濃度の関係を Fig. 11 亿示す. 水蒸気濃度が $5 \%$ 付近 は $\mathrm{T}$ 炭, 10〜 $14 \%$ は $\mathrm{N}$ 炭である. 水蒸気濃度が増大する と $\mathrm{H}_{2} \mathrm{~S}+\mathrm{COS}$ 濃度は増大した. Fig.11の点線はEq.(6)か ら，一点鎖線はEq.(7)から計算した，温度が1193Kにお ける平衡 $\mathrm{H}_{2} \mathrm{~S}$ 濃度である。

$\mathrm{H}_{2} \mathrm{~S}$ とCOSの生成比脱硫炉出口の $\mathrm{H}_{2} \mathrm{~S}$ とCOS濃度 の関係は，1173〜1243K では Fig. 12に示すように，ガス 組成に関わらず $\mathrm{H}_{2} \mathrm{~S}: \operatorname{COS}$ が 10: 1 とほぼ一定となった。 Fig. 12 に $\mathrm{H}_{2} \mathrm{~S}+\mathrm{CO}_{2}=\mathrm{COS}+\mathrm{H}_{2}$ の JANAF のデータから 計算した化学平衡を記した. 実験のCOS值は平衡COS値 よりあ大きな值となった。

\section{3. 考察}

\section{$3 \cdot 1$ 脱硫装置形式による脱硫性能の差}

石炭ガス化炉へ直接石灰石を供給すると高い脱硫性能

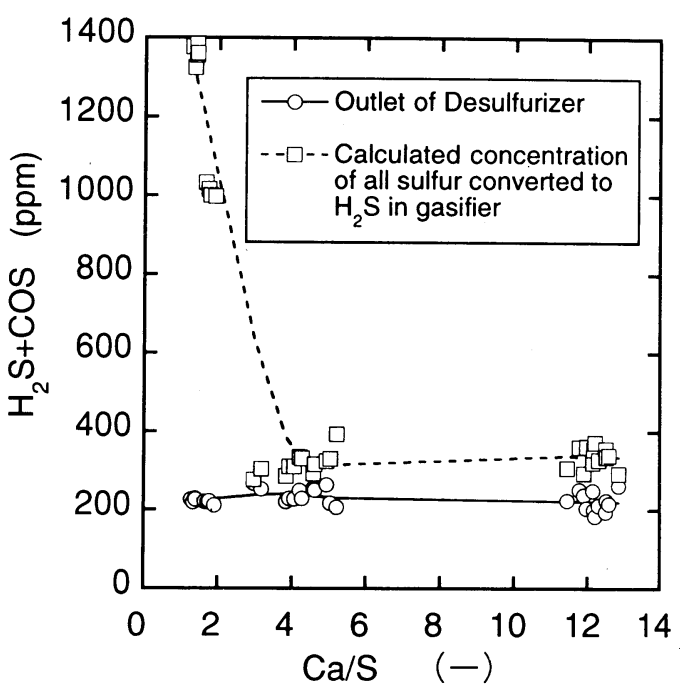

Fig. 10 Effect of $\mathrm{Ca} / \mathrm{S}$ on $\mathrm{H}_{2} \mathrm{~S}+\mathrm{COS}$ concentration of desulfurizer

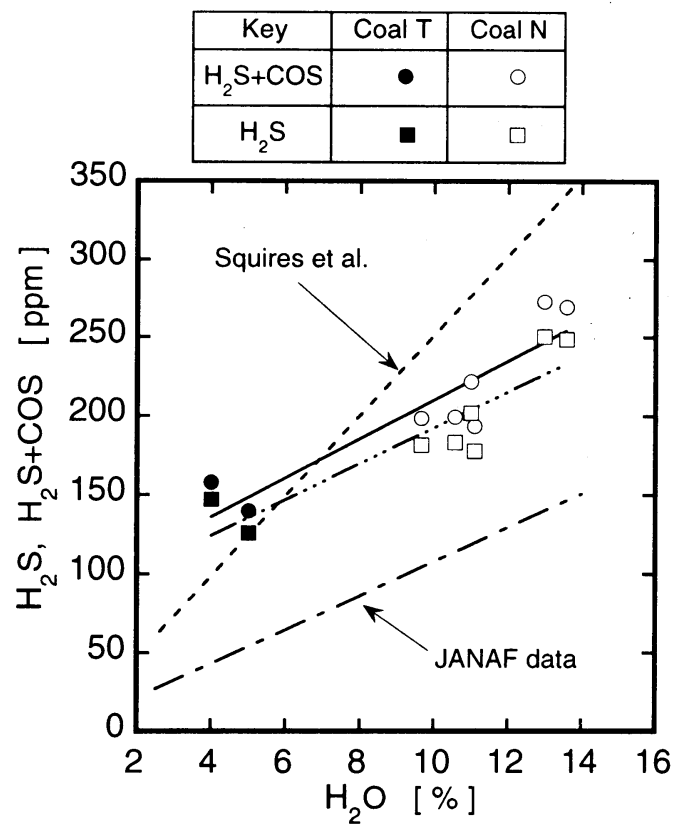

Fig. 11 Effect of $\mathrm{H}_{2} \mathrm{O}$ concentration of gasifier on $\mathrm{H}_{2} \mathrm{~S}+\mathrm{COS}$ concentrations at desulfurizer outlet

が得られないのは，以下に説明するように一つは石灰石 の滞留時間が短いためであり，もう一つは $\mathrm{CaS} と \mathrm{O}_{2}$ の反 応が生じるためと考えられる。

石灰石滞留時間 実験に用いた流動層石炭ガス化炉 の流動媒体に適した 0.5 1.5 mm の石灰石の $\mathrm{CaS}$ 生成率 を $50 \%$ 以上とするには，例えば Fig. 3 の左図に示すよう に $1223 \mathrm{~K}$ では約 $120 \mathrm{~min}$ 以上必要である。本実験の石炭 


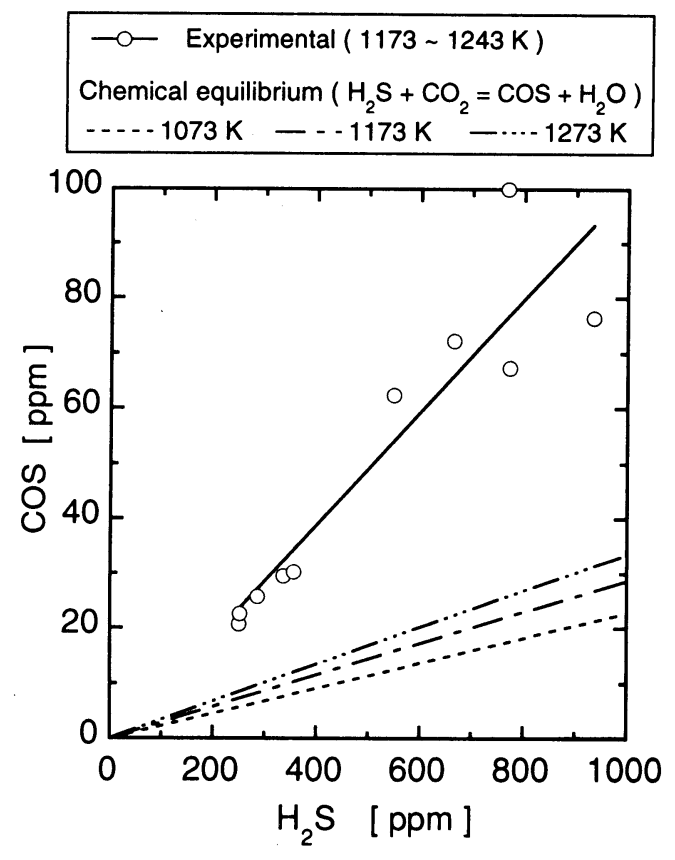

Fig. 12 Relation between $\mathrm{H}_{2} \mathrm{~S}$ and $\mathrm{COS}$ in desulfurized gas

の滞留時間は $15 \mathrm{~min}$ 程度である。一般的には必要な石炭 の滞留時間は約 $20 \sim 40 \mathrm{~min}$ である。 そのような滞留時間 では，本実験の粒子径の石灰石の $\mathrm{CaS}$ 生成率を $50 \%$ 以上 にできない。

$\mathrm{CaS} と \mathrm{O}_{2}$ の反応 Fig. 3 の固定層実験ではセットア ップに使用した $\mathrm{CO}_{2}$ から $\mathrm{H}_{2} \mathrm{~S}$ あるいは $\mathrm{SO}_{2}$ へのガスの切 り替え時の逆混合や, $\mathrm{H}_{2} \mathrm{~S}$ の吸着, 分解, $\mathrm{SO}_{2}$ 濃度の計 測応答遅れがあり, 初期反応速度を定められない, 反応 開始から 5 分間で比較してみる. Fig. 3 の脱硫実験の 5 分間の $\mathrm{CaS}$ 生成率は約 $2 \%$ である.Fig. 3 の酸化実験の 粒子分析の結果からは, 約10分で生成した $\mathrm{CaS}$ の $45 \%$ が $\mathrm{O}_{2}$ と反応したてとになり，それは全 $\mathrm{Ca}$ の $27.3 \%$ 亿当たる. 5 分後には $\mathrm{CaS}$ の $\mathrm{CaO}$ あるいは $\mathrm{CaSO}_{4}$ 酸化量は全 $\mathrm{Ca}$ の 約 $20 \%$ 以上と推定される. てれより反応初期の酸化速度 は $\mathrm{CaS}$ の平均生成速度よりも 1 析程度オーダーの速い反 応之推定ざれる。

石炭ガス化炬では，供給した酸素ガスは速やかに石炭 等と燃焼反応等で消失しており， $\mathrm{O}_{2}$ の存在領域は小さい と考えられる. しかし $\mathrm{CaS}$ の $\mathrm{O}_{2}$ による酸化速度は石灰石 から $\mathrm{CaS}$ が生成する速度よりも 1 桁以上大きいので, 脱 硫生成物である $\mathrm{CaS}$ の $\mathrm{O}_{2}$ による分解量が無視できないと 考えられる。

\section{$3 \cdot 2$ 脱硫反応機構}

Figs. 4, 5, 6 から, 脱硫反応が進む場合は常に $\mathrm{CaO}$ 生成 率よりあ $\mathrm{CaS}$ 生成率が大きくなるととはない，また，力
ルシネーション反応が進まない場合は CaS生成率は数\% 以下である. Fig. 4 の $1223 \mathrm{~K}$ の例のようにカルシネーシ ヨン反応速度が速く，反応が速く完結してしまうと，そ の後の $\mathrm{CaS}$ 生成率の増加が止まってしまう。乙れより， 石灰石のカルシネーション反応が進行し，ポーラスとな り石灰石粒子内部の反応表面積が増大を続けている間は, $\mathrm{CaS}$ と $\mathrm{H}_{2} \mathrm{~S}$ の反応が進むと考えられる．60～ $80 \%$ の高い $\mathrm{CaS}$ 生成率を得るにはカルシネーション速度と脱硫反応 速度を同程度とする必要があり, $\mathrm{CO}_{2}$ 分圧に応じてカル シネーション速度は変化するので $\mathrm{CO}_{2}$ 分圧に応じた最適 な脱硫温度を制御する必要がある。

$1223 \mathrm{~K}$ の水蒸気濃度が $5 \%$ ではEq. (7) による平衡 $\mathrm{H}_{2} \mathrm{~S}$ 濃度は $60 \mathrm{ppm}$ であり，今回の実験値は $140 \mathrm{ppm}$ でありそ れらの値には開きがある. Fig.11亿示すように脱硫炉出 口の $\mathrm{H}_{2} \mathrm{~S}$ 濃度の水蒸気濃度依存性は Eq. (7) の $\mathrm{CaO}$ 之 $\mathrm{H}_{2} \mathrm{~S}$ の反応の平衡 $\mathrm{H}_{2} \mathrm{~S}$ 濃度と同様の傾向を示している.

$\mathrm{H}_{2} \mathrm{~S}$ 濃度が $940 \mathrm{ppm}$ と高い Fig. 6 の温度 $1219 \mathrm{~K}$, 圧力 1.6 MPaでは, $\mathrm{CaS}$ 生成率が $50 \%$ の脱硫反応速度は, $\mathrm{CaS}$ 生成率が $0 \%$ の脱硫反応速度の約 2 分の 1 である。 $\mathrm{CaS}$ 生成率が大きくなると反応速度が低下するのは，石灰石 粒子内へのガスの拡散抵抗が大きくなるためと考えられ る.

Fig.10の流動層実験では $\mathrm{Ca} / \mathrm{S}$ 比が 1.4 の場合はCaS生 成率が $60 \%$ であり, $\mathrm{Ca} / \mathrm{S}$ 比が 12.5 ではCaS生成率は $3 \%$ である. $\mathrm{Ca} / \mathrm{S}$ 比が 12.5 の脱硫炬出口の $\mathrm{H}_{2} \mathrm{~S}+\mathrm{COS}$ 濃度 は, $\mathrm{Ca} / \mathrm{S}$ 比が 1.4 の場合よりも約 $20 \mathrm{ppm}$ 小さい程度で大 差ない. $\mathrm{H}_{2} \mathrm{~S}$ 濃度が $200 \mathrm{ppm}$ と低くなり平衡濃度に近づ くと, $\mathrm{CaS}$ 生成率か脱硫反応速度に与える影響は小さく なる．石灰石の $\mathrm{H}_{2} \mathrm{~S}$ にる脱硫速度については更に詳細 な検討が必要である.

\section{結言}

固定層扰よび流動層の実験装置を用い石灰石と $\mathrm{H}_{2} \mathrm{~S}$ か ら $\mathrm{CaS}$ が生成する反応特性を検討し次のような知見を得 た.

1）石灰石を流動層石炭ガス化炬へ供給する脱硫方法は, 高効率脱硫に適さない，その理由を次仁す。

a） $0.5 \sim 1.5 \mathrm{~mm}$ 程度の粒径では， $50 \%$ 以上の $\mathrm{CaS}$ 生 成率を達成するために必要な粒子滞留時間を通常 の石炭ガス化炉では確保できない。

b) 脱硫生成物の $\mathrm{CaS}$ 之酸素が反応し $\mathrm{CaS}$ が分解する 反応速度が脱硫反応速度よりも速い。

2) カルシネーション反応が進行し, 石灰石がポーラス となり石灰石粒子内部の反応表面積が増大する条件 で, カルシネーション速度と $\mathrm{CaS}$ の生成速度がほぼ 等しいと, $\mathrm{CaO}$ と $\mathrm{H}_{2} \mathrm{~S}$ の反応で $\mathrm{CaO}$ の 60 〜 $80 \%$ が 
$\mathrm{CaS}$ 一転換する。

3）石炭ガス化炉の後流に石灰石の流動層を形成させた 脱硫炉を別置し, 石炭ガス化ガスを流すことにより $\mathrm{Ca} / \mathrm{S}$ 比 $1.7, \mathrm{H}_{2} \mathrm{O}$ 濃度 $5 \%$ で脱硫後の $\mathrm{H}_{2} \mathrm{~S}+\mathrm{COS}$ 濃

度を $140 \mathrm{ppm}$ に低減した。

次世代石炭ガス化炉 (AFGC) の運用条件と石灰石による $\mathrm{H}_{2} \mathrm{~S}$ 脱硫条件は合致し, 石灰石を脱硫剤とした高温, 加 圧の脱硫方法が明らかとなった。

\section{Nomenclature}

$k=$ initial reaction rate constant defined by Eq. (5) $\left[\mathrm{Pa}^{-1} \mathrm{~min}^{-1}\right]$

$P_{\mathrm{H}_{2} \mathrm{O}}=\mathrm{H}_{2} \mathrm{O}$ pressure

$P_{H_{2} S}=\mathrm{H}_{2} \mathrm{~S}$ pressure

$r=$ initial reaction rate of $\mathrm{CaS}$ formation $\left[\mathrm{min}^{-1}\right]$

$T$ = temperature

\section{Literature cited}

1) Chase, M.W. Jr., C.A. Davies, J.R.Downey, Jr., D.
J.Frurip, R.A.McDonald and A.N.Syverud: Jou. Phy. \& Chem, Ref. Data, 14, JANAF Thermochemical Tables Third Edition (1985)

2) Goyal, A., B.G.Bryan, A.Rehmat, J.G.Patel and M.R.Ghate: Energy Sources, 12, 161-179 (1990)

3) Kawahara,T., K.Nakajima, K.Sato, H.Kameyama and K. Yoshida: Nippon Kagakukai-shi, 6, $1066-$ 1071 (1980)

4) Minchener, A.J., M.S.Arnold and S.G.Dows: Proc. 12 th Int. Conf. Fluidized Bed Combustion, San Diego, No. 2, 1129-1132 (1993)

5) Morooka, K. : Jou. Japan Inst. Energy, 72, 403-404 (1993)

6) Fujioka, Y., S.Shirakawa, S.Hozumi and J.Arai: Proc. World Congr. 3 Chem. Eng., vol.1, 495-500 (1986)

7) Rehmat, $\mathrm{A}$ and A. Goyal: Proc. 12 th Int. Conf. Fluidized Bed Combustion, San Diego, No.2, 1133 - 1142 (1993)

8) Squires, A.M., R.A.Graff and M.Pell : Chem. Eng. Progress Symp. Ser., 67, 23-35 (1971)

9) Weinzierl, K. : VGB Kraftwerkstechnik, 69, 553-557 (1989)

\section{Evaluation of High Temperature Desulfurization of Coal Gasification Gas with Limestone}

Yuichi Fujioka, Yoshihiko Tsuchiyama and Kimishiro Tokuda

Nagasaki Research and Development Center,

Mitsubishi Heavy Industries, LTD., Nagasaki, 851-03

Fumiya Nakashima and Satoshi Uchida

Power Systems Engineering Department,

Mitsubishi Heavy Industries, LTD., Yokohama, 220

Key Words: Desulfurization, Limestone, Coal Gasifier, Fluidization, Hydrogen Sulfide, High Temperature

Experiments on the reaction between limestone and hydrogen sulfide were conducted with fixed bed and fluidized bed experimental apparatus under high pressures and temperatures. This study made it clear why desulfurization efficiency was low when limestone was directly fed into a coal fluidized bed gasifier. The first reason is that the residence time of limeston in the gasifier is too short. The second reason is that the oxidation rate of $\mathrm{CaS}$ is larger than the formation rate of $\mathrm{CaS}$. When the rate of $\mathrm{CaS}$ formation was nearly equal to the rate of calcination, the $\mathrm{CaS}$ mole fraction of limestone was above $60 \%$. Passing coal gasification gas through a limestone fluidized bed in the fluidized bed experimental apparatus decreased $\mathrm{H}_{2} \mathrm{~S}$ concentration at the fluidized bed to about $140 \mathrm{ppm}$. 